
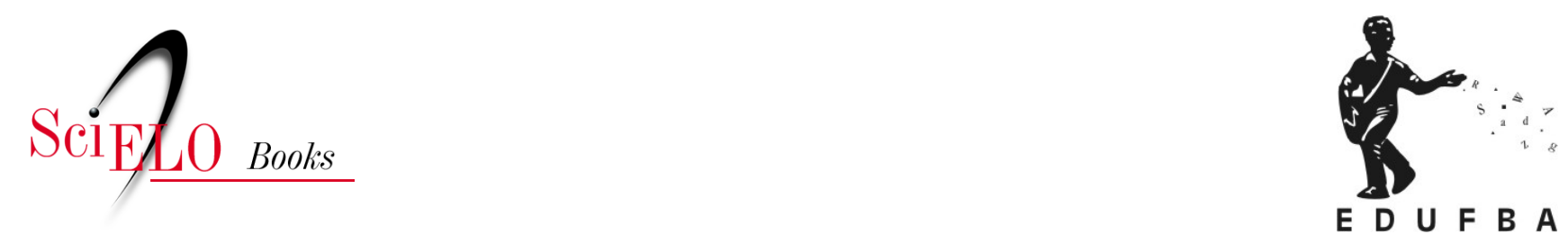

\title{
Blacks sob vigilância
}

\author{
Luciana Xavier de Oliveira
}

\section{SciELO Books / SciELO Livros / SciELO Libros}

OLIVEIRA, L. X. Blacks sob vigilância. In: A cena musical da Black Rio: estilos e mediações nos bailes soul dos anos 1970 [online]. Salvador: EDUFBA, 2018, pp. 159-187. ISBN: 978-85-232-18720. https://doi.org/10.7476/9788523218720.0005.

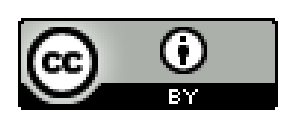

All the contents of this work, except where otherwise noted, is licensed under a Creative Commons Attribution $\underline{4.0 \text { International license. }}$

Todo o conteúdo deste trabalho, exceto quando houver ressalva, é publicado sob a licença Creative Commons Atribição 4.0.

Todo el contenido de esta obra, excepto donde se indique lo contrario, está bajo licencia de la licencia Creative Commons Reconocimento 4.0. 


\section{Blacks sob vigilância}

A cena Black Rio, ao alcançar a grande mídia, acabou por despertar críticas e reações que seguiam, basicamente, duas frentes. A primeira defendia a tese de que o Brasil era uma democracia racial, obtida graças à miscigenação de três raças: o branco português, o negro africano e o índio nativo. Segundo essa corrente, o país seria o paraíso do mulato, não havendo atualmente grandes problemas de preconceito racial, o que tornaria qualquer movimento negro artificial e deslocado da realidade nacional, uma tendência importada dos EUA que poderia ser prejudicial ao Brasil ao pregar uma marcada diferenciação racial que possivelmente conduziria a conflitos e tensões. (CAVALCANTI, 1981, p. 3) Havia ainda o receio de um distanciamento de uma autêntica cultura brasileira, alienando os participantes não apenas da "verdadeira” identidade nacional, como também de possíveis ações políticas eficazes de conscientização racial que deveriam ser pautadas em tradições afro-brasileiras. Outras críticas, advindas de uma esquerda com tendências comunista-marxistas, partiam do pressuposto de que o problema da desigualdade no Brasil seria uma questão de classe social e não de ordem racial, pressupondo que a união e a luta de classes dispensariam a necessidade de um movimento negro com ênfase na questão étnica. 


\section{A esquerda nacionalista e a alienação do soul}

"Black Rio: o orgulho (importado) de ser negro no Brasil", texto publicado em 17 de julho de 1976, é considerada a primeira matéria jornalística de relevo que trouxe para a Black Rio os holofotes da imprensa e chamou a atenção da cidade para a cena dos bailes. De autoria de Lena Frias (Marlene Ferreira Frias, 1943-2004), a reportagem de capa do segundo caderno do Jornal do Brasil revelava os bastidores do movimento, mas denunciava, nas entrelinhas, a crítica à vocação dos seus participantes para a celebração de uma identidade vista como "americanizada".

Lena Frias, naquele momento, se consagrava como jornalista e pesquisadora influente da música popular e cultura brasileira. Tinha trânsito livre entre compositores e intelectuais de esquerda e era ligada ao universo do samba e do Carnaval particularmente. No Jornal do Brasil, produziu outras reportagens de grande teor investigativo - chegando a se mudar para a Cidade de Deus para uma reportagem sobre a comunidade - e era entusiasta e amiga de artistas populares, como Clementina de Jesus e Candeia, defensora da "autêntica” cultura popular. ${ }^{1}$ Falar sobre a Black Rio, de certa forma, era uma novidade em relação aos seus temas comuns de reportagem. Convidada por um contínuo do jornal, um jovem branco chamado Everaldo - que se vestia como black para ir às festas -, Lena Frias foi pela primeira vez a um baile soul no clube Maxwell, em Vila Isabel, Zona Norte do Rio. ${ }^{2}$

A jornalista - ela mesma afrodescendente - também considerava o crescimento da Black Rio como um reflexo da segregação racial, portanto, não totalmente desprovido de valor e legitimidade. No artigo, há momentos em que a visão neutra da repórter apenas narra detalhes sobre os fatos, mas há

1 Além de jornalista, Marlene Ferreira Frias (1944-2004) pesquisava cultura popular e era muito ligada ao universo do samba carioca. Foi jurada durante alguns anos de desfiles de escolas de samba, fez parte do Conselho de Carnaval da Cidade do Rio de Janeiro, do Conselho Estadual de Cultura do Rio de Janeiro e, com Hermínio Bello de Carvalho e Nei Lopes, escreveu textos para o livro Rainha Quelé (2001), com organização de Heron Coelho, sobre a vida de Clementina de Jesus. Lena Frias faleceu em 2004, ano de seu último trabalho, um release sobre um CD de Dona Ivone Lara.

2 De acordo com José Sergio Rocha, jornalista, no site Agenda do Samba-Choro, em 12 de maio de 2004. Disponível em: <http://www.samba-choro.com.br/noticias/arquivo/9139>. 
passagens em que se posiciona favoravelmente em relação aos bailes, denunciando o racismo contido na repressão às festas e aos frequentadores. Mas, de forma geral, o texto ecoa um discurso de esquerda e um viés nacionalista, que considerava inautênticas e alienantes manifestações que tivessem um cunho "internacionalista" e "mercantilizado". No mesmo Jornal do Brasil, um ano depois, em 1977, o Secretário Municipal de Turismo do Rio de Janeiro, Pedro de Toledo Pizza, já declarava que "o Black Rio é um movimento comercial com uma filosofia racista”. (TURISMO..., 1977, p. 20)

Se, logo no título, percebe-se a ênfase irônica do argumento que critica a prática da "importação" de formas culturais estrangeiras, a denúncia dessa perspectiva política fica clara em passagens como "sabem tanto de soul quanto ignoram de cultura brasileira”. (FRIAS, 1976, p. 4) O tom da reportagem era de que as classes menos privilegiadas e a população negra deveriam assumir uma atitude mais "nacionalista", mesmo que ela reconhecesse que "embora sobre a cópia já se criem originalidades". Ao longo do texto, a jornalista também realçava a falta de um suposto sentido político para o movimento, enfatizando seu caráter de "modismo" e "imitação", pois "Frias se preocupava menos com a imitação da cultura estrangeira praticada por roqueiros brancos do que com a aparente alienação dos afrodescendentes em relação aos símbolos estabelecidos de uma cultura nacional afro-brasileira”. (ALBERTO, 2009, p. 18) Isso, de certa forma, endossava a ideia da jornalista de que era uma manifestação inofensiva e que, portanto, não deveria ser alvo de repressão policial, rejeitando também a hipótese de que o movimento seria uma espécie de mobilização que pregava a divisão racial, temida pela ditadura. Para Frias, os participantes, produtores, DJs e artistas estariam mais interessados em lucrar com o negócio do que em incentivar a formação de uma consciência política e racial. Esse não foi o primeiro artigo a abordar o fenômeno da Black Rio, como alega Vianna (1987, p. 57), mas foi a matéria que ganhou mais repercussão por conta da amplitude e profundidade com a qual tratou o tema.

$\mathrm{Na}$ esteira do artigo do Jornal do Brasil, vários outros jornalistas e críticos de esquerda de suplementos culturais tradicionais, revistas populares e jornais especializados em música logo amplificaram a crítica de Frias em relação à natureza comercial e importada do soul. Algumas semanas depois, 
Tárik de Souza (1976, p. 10), também do Jornal do Brasil, publicou o artigo intitulado "Soul: sociologia e mercado", em que comparava a história do jazz e da soul music nos EUA com as compilações e coletâneas brasileiras lançadas em vinil com o nome das equipes de som mais famosas e considerando essas gravações como " $10 \%$ de alma e $90 \%$ planejado marketing”. Além de criticar o soul como um movimento comercial, esses articulistas deixavam claras suas perspectivas, que evidenciavam a falta de vocação política e a inexistência de consciência racial entre os participantes da cena.

O questionamento à legitimidade do fenômeno e a ênfase em sua falta de expressão política estavam presentes também no desprezo em relação aos participantes. Para alguns jornalistas, o soul apenas demonstrava uma adesão a fórmulas musicais mercantis estrangeiras, e dificilmente poderia sugerir alguma coisa para além do mero conformismo de pessoas simples, despreparadas para resistir aos bombardeios de modismos propagados pelos meios de comunicação. (ALBERTO, 2009, p. 26) E mesmo reconhecendo uma motivação de protesto racial, José Ramos Tinhorão era enfático ao apontar a Black Rio como uma cópia, mas inadequada ao contexto brasileiro, enfatizando a questão da classe e da nacionalidade como fatores que deveriam prevalecer sobre a etnicidade na luta pelo fim da desigualdade social - e não racial:

[...] é que o grande desejo dos brasileiros de pele negra das grandes cidades (ao menos os do Rio e de São Paulo, onde o movimento black já existe) é parecer o mais possível com os negros norte-americanos. Isto é, deixarem de ser trabalhadores explorados num contexto subdesenvolvido, para se tornarem a imagem de trabalhadores explorados num contexto superdesenvolvido. (TINHORÃO, 1977, p. 2)

As acusações mais contundentes de inautenticidade do Black Soul vieram do jornal O Pasquim, representante máximo da esquerda alternativa na imprensa do período. O crítico musical Roberto Moura (1977, p. 2-8), no artigo "Carta aberta ao Black-Rio", descreve a cena do soul carioca como uma insidiosa campanha publicitária neocolonialista que visava simplesmente criar condições para o consumo dos excessos produzidos pela indústria cultural estrangeira, apontando para a falta de consciência política dos blacks, vistos 
como "não pensantes" e apenas preocupados com a aparência e os ditames da moda. ${ }^{3}$ Até mesmo o poeta Ferreira Gullar veio a público criticar o movimento, "negando significado sociológico ao black-jovem". De São Paulo, a voz do maestro Júlio Medaglia, um dos mentores musicais da Tropicália, também se levantou contra as influências estrangeiras da musicalidade americana, que poderiam macular a autêntica música afro-brasileira, em entrevista publicada na Folha de São Paulo em 10 de junho de 1977:

O que existe de mais trágico por trás de tudo isso é que eles estão tentando impingir um ritmo, uma harmonia e um som que nada têm a ver com a nossa musicalidade. E o pior é que estão se valendo de um bando de inocentes úteis, que mal sabem avaliar a importância do tesouro musical, que herdaram da África. (SANTOS, 1977, p. 32)

O compositor Caetano Veloso rebateu críticas a seus novos trabalhos, que consideravam que os artistas não poderiam se alienar da realidade e deveriam refletir em suas canções suas consciências políticas e seus desagravos em relação à repressão. O auge do patrulhamento aconteceu durante a turnê do álbum Bicho, quando o cantor se apresentou ao vivo acompanhado pela Banda Black Rio. A faixa de trabalho foi a composição "Odara”, que "apresentava bastante explícita a inspiração no funk, especialmente a forte presença do contrabaixo". (RODRIGUES, 2003, p. 37) O trabalho, que tinha uma proposta claramente voltada para a dança, foi duramente criticado pelas patrulhas ideológicas, visto como alienado. O LP Refavela (Philips, 1977), de Gilberto Gil, também foi criticado - chamado de "Rebobagem" pelo crítico Tárik de Souza na revista Veja.

O debate em torno das patrulhas ideológicas se refere a um momento muito particular dos anos 1970, em que intelectuais e formadores de esquerda deliberadamente passaram a cobrar uma arte engajada, criticando

3 Outro artigo do Pasquim, escrito por Aldir Blanc, intitulado "Safari", narrava a visita do jornalista a uma festa soul, comparando a experiência a uma caminhada pela África "desconhecida e escura", descrevendo os participantes como uma tribo liderada por um tirano, que falavam uma língua "estranha" intercalada com frases em inglês, como "oh yeah", e que adoravam os "deuses brancos do soul, os executivos das gravadoras". (O Pasquim, ago. 1977) 
manifestações que não se enquadrassem em um viés de contestação política. As patrulhas ideológicas estabeleciam claramente uma distinção de valor entre "músicas para dançar" e "músicas para pensar". Caetano denunciava os cadernos de cultura dos principais jornais e revistas do país, que seriam dominados por uma esquerda repressora representada por críticos que pretendiam policiar a música popular no Brasil. ${ }^{4}$ Se os próprios integrantes da MPB poderiam ser criticados por produzir canções e discos que privilegiassem a festa, a alegria, o ritmo e a dança, o que dirá de todo um movimento periférico, popular, baseado em bailes, nos quais se ouvia e se dançava música americana? Risério (1981, p. 32) ainda complementa: "Pior ainda é que esses setores supostamente 'progressistas' falavam em nome das massas oprimidas do país exatamente para condenar uma das manifestações estéticas e sociais mais vivas dessas mesmas massas oprimidas”.

A vida nas grandes cidades brasileiras foi marcada por movimentos jovens contraculturais, algumas vertentes diretamente descendentes do Tropicalismo, criado entre os anos de 1967 e 1968. De certa forma, por seu caráter mais fluido e sem uma ideologia consolidada nem preocupação diretamente política e institucional, esses movimentos eram vistos sem um claro propósito ideológico, muitos acusados de alienação política. Claramente, havia uma desilusão em relação às organizações tradicionais de esquerda, especialmente por esses centrarem o foco da revolução na classe, em detrimento de questões como raça e gênero, deixando de lado aspectos mais subjetivos. Novas demandas aparecem na esfera pública com o surgimento de movimentos sociais e políticos independentes representando negros, mulheres, gays e trabalhadores. O corpo e o físico natural, em um contexto pré-culto à boa forma dos anos 1980, era valorizado, acompanhando a liberdade das novas ideias e o fluxo mais livre do pensamento, o que não deixava de ser revolucionário e angariava mais adeptos que adotavam uma atitude contra a "caretice". Essa proposta de uma articulação política por outras vias que não a institucional nem por meio da luta armada ganhava fôlego, especialmente em um

4 Ver: Os críticos musicais, segundo Caetano Veloso, Jornal O Globo, Rio de Janeiro, 31 jan. 1979, p. 41. 
momento que marcava o fracasso das tentativas de revolução insurrecional durante o governo militar.

Mesmo alguns militantes, intelectuais e artistas negros viam com suspeição o Black Soul, temendo radicalizações e, mais ainda, o caráter comercial do movimento, o que não beneficiaria seus participantes negros e pobres. "Sinto que há uma tentativa de radicalização racial no Brasil. Acho que isso é uma jogada perigosa de grupos que estão estimulando o racismo como forma de planejamento de marketing para lançamento de linhas de produtos especificamente negros", comenta o publicitário negro José Jorge da Costa. (FRIAS, 1976, p. 5) O movimento estaria potencializando os lucros para empresários brancos, e não para a população negra. Apesar de diferenças ideológicas e de propósitos, Lena Frias atuava em um jornal vinculado à esquerda, como também era Abdias do Nascimento, famoso intelectual negro e ativista político. Embora o soul fosse reconhecido como um instrumento que favorecesse a união da comunidade negra na época, suas expressões estéticas e musicais eram vistas com certa desconfiança por alguns militantes negros que ainda separavam o estético do político. No entanto, essa visão aos poucos se modificou, a partir do momento em que essa produção cultural passou a ser vista de maneira positiva e incentivadora de uma mudança de comportamento frente à questão racial. (GOMES, 2006, p. 224) Em seu livro O genocídio do negro brasileiro (1979), Abdias critica a suposta alienação do soul, mas tenta identificar suas causas e relativizar seus efeitos a longo prazo. Para o intelectual, os blacks utilizavam símbolos e atos de consumo "alienados", mas que poderiam ter um valor positivo de afirmação racial e "espírito rebelde":

Essas realidades fazem compreensível que nas grandes cidades como o Rio de Janeiro e São Paulo a juventude negra canalize suas ansiedades para movimentos como estes, intitulados de 'Black Mad' ou de 'Soul' [...] os quais parecem utilizar a música, a dança, o vestuário, o corte de cabelo e outros símbolos como demonstrativos de inconformismo e confrontação. E também para evadir do sentimento de frustação, mesmo ao custo de recorrer a modelos alienados, cuja origem ostensiva são os negros dos Estados Unidos. Quem pode adivinhar se essa iniciativa, aparentemente equivocada, 
não se transformará num movimento de tomada de consciência e de uma afirmação original? (NASCIMENTO, 1978, p. 131)

Maria Motta-Maués (2009, p. 715) sinaliza que lideranças negras haviam incorporado a visão estereotipada da vocação e gosto atribuído às populações afro-brasileiras pelas festas e eventos de lazer. Especialmente militantes ligadas à imprensa negra e associações mais tradicionais consideravam como atividades políticas mais legítimas "reuniões, edição de jornais, manifestações públicas”, eventualmente saraus, cursos e outras ações educacionais, enquanto que as manifestações associadas à sociabilidade, a divertimentos, festas - que, inclusive, sempre estiveram presentes na história das entidades de movimento negro - eram vistos naquele momento como empecilhos à mobilização política e à conscientização racial por abrirem mão de uma ação pedagógica concreta. De certa forma, esse tipo de discurso das lideranças negras reproduzia um desejo de se desviar da imagem estereotipada dos negros como malandros, boêmios, bêbados, viciados, em prol da construção de uma imagem de honestidade, intelectualidade, respeitabilidade e de cumprimento dos deveres. Como Márcia Motta-Maués (2009, p. 719) considera, desde a década de 1930, havia uma continuidade no tratamento a determinadas manifestações populares, especialmente aquelas associadas a grupos negros populares, acusadas de serem perniciosas e de impedirem a elevação moral dos indivíduos - e essa era a intenção primordial dos primeiros movimentos negros.

Assim, o soul recebia uma dupla crítica: era tanto um "modismo" inútil, alienado e infértil de ideias, com uma inflexão deliberadamente comercial marcada pela importação de produtos culturais de uma América imperialista, como também representava uma "traição" ao patrimônio cultural brasileiro, pois seus participantes abraçavam o soul e deixavam de lado o samba, tido como a mais autêntica tradição afro-brasileira nacional. E esquerdistas tradicionais criticavam o Black Soul, alegando tratar-se de mero entretenimento, produzido e "commoditizado" pelo capital multinacional, que desviava a atenção da política de classes. (DUNN, 2009, p. 208) Vale notar que os blacks, naquele momento, recebiam críticas muito mais acirradas do que a juventude branca roqueira, influenciada, da mesma forma, por tendências 
americanas. Isso sugeria a escamoteação de um tom racista e discriminatório ao poupar dessas críticas as formas de lazer e consumo das elites e classes médias brancas, desmerecendo a Black Rio, esta usufruída por uma juventude negra menos privilegiada. Dom Filó, em entrevista à revista Veja, ofereceu uma resposta às críticas:

Por que se aceita com toda naturalidade que a juventude da zona sul se vista de jeans, dance o rock, frequente discoteca e cultue Mick Jagger, enquanto o negro da zona norte não pode se vestir colorido, dançar o soul e cultuar James Brown? Por que o negro tem que ser o último reduto da nacionalidade ou da pureza musical brasileira? Não será uma reação contra o fato de ele haver abandonado o morro? Contra uma eventual competição no mercado de trabalho? Por que o negro da zona norte deve aceitar que o branco da zona sul (ou da zona norte) venha lhe dizer o que é autêntico e próprio do negro brasileiro? Afinal, nós que somos negros brasileiros nunca nos interessamos em fixar o que é autêntico e próprio do branco brasileiro. (BLACK RIO, 1976, p. 158)

Para José Ramos Tinhorão, um dos mais ferrenhos críticos musicais e severo detrator da "americanização" da cultura brasileira, os discos de soul brasileiro lançados pelas gravadoras estrangeiras representadas pela WEA representariam uma "violência cultural consentida" e "exemplos de como a dominação econômica estrangeira, disfarçada por um desenvolvimento à base de importação maciça de capitais e tecnologia pode acarretar a contrapartida cultural de que, ser atual... é imitar o que se importa de mais moderno!”. Na crítica intitulada "Protesto ‘black' é fonte de renda ‘white”, Tinhorão (1977) considera esse um efeito da demanda de um novo mercado formado por consumidores negros em processo de ascensão socioeconômica diante de um maior acesso ao ensino superior por meio do crescimento da oferta de vagas em faculdades particulares, processo que ele compara à "expansão dos supermercados":

Levados normalmente a contestar as verdades oficiais vigentes, pela dificuldade que encontram em seu processo de ascensão em face 
da marca da cor, que os identifica tradicionalmente com as classes subjugadas (escravos até 1888, trabalhadores não qualificados depois), os brasileiros de pele escura dos grandes centros urbanos foram levados a projetar-se na imagem das camadas equivalentes nos Estados Unidos. E, assim - inspirados pelas sugestões dos filmes de cinema e de televisão, pelas reportagens de revistas e pelas novidades musicais - inclinaram-se não a tomar consciência da sua realidade de trabalhadores brasileiros freados em seus propósitos de melhorias de vida pela barreira da cor, mas a imitar os processos de luta criados pelos negros americanos: a contestação pela extravagância, o orgulho pessoal, a formação de núcleos próprios etc. Mas tudo isto, apenas - e que é revelador da falta de sentido critico ideológico do seu movimento - apenas na área do lazer. (TINHORÃO, 1977, p. 2)

Da sua maneira, Tinhorão (1977) representava a visão da esquerda de que a Black Rio era uma questão de comércio, consumo e "indústria do lazer", que dissolvia reivindicações e pautas políticas em favor da diversão e da moda. Os negros brasileiros seriam, pois, inconscientes em seu desejo de se parecer com os negros norte-americanos - "Isto é, deixarem de ser trabalhadores explorados num contexto subdesenvolvido, para se tornarem a imagem de trabalhadores explorados num contexto superdesenvolvido". O crítico também apontava a questão da classe como superior às ações baseadas na raça ou na cultura. Foram os críticos culturais que ajudaram a difundir a expressão “vazio cultural”, que estigmatizou os anos 1970 como um período de suposta inatividade, "desbunde" e ausência de produções artísticas de cunho mais flagrantemente político. Bahiana (1980, p. 42) enumera algumas razões para esse "esvaziamento", que teria levado o público jovem a se voltar para o consumo descompromissado da música internacional: o clima repressivo da ditadura - que se aprofundou entre 1969 e 1975 -, a saturação da fórmula dos festivais, a prisão e exílio compulsório de intelectuais e artistas de esquerda, que acompanharia o desejo das novas gerações de "admirar e, consequentemente, tentar imitar com fidelidade a música que vinha de fora”.

Por volta de 1972, a fase mais repressiva do governo militar, a oposição armada foi, em grande parte, reprimida, com a prisão e exílio de muitos 
ativistas políticos. A agitação cultural do final da década de 1960 foi substituída por uma atmosfera de desilusão política, e os problemas sociais e econômicos se agravaram. "Com quase todas as vias de oposição política organizada bloqueadas, a juventude urbana da classe média se voltou para buscas mais pessoais e espirituais” (DUNN, 2009, p. 198), tendência que se mostrava predominante em várias cidades do mundo, condicionando a emergência de uma série de movimentos contraculturais. Essa nova inclinação contracultural no Brasil ganhou o sobrenome de "desbunde" pela esquerda tradicional. O termo jocoso correspondia ao ressurgimento de controvérsias públicas entre vários setores da oposição a respeito do papel dos artistas e intelectuais, em um questionamento da eficácia social e política da arte e da cultura. Foi o momento do surgimento das patrulhas ideológicas ligadas a críticos e militantes ortodoxos de esquerda. Para estes, em um momento de desesperança e desilusão diante da manutenção do regime com guerrilhas, torturas, sequestros e assassinatos, quaisquer produtos culturais que ousassem investir em discursos positivos sobre a realidade, exaltando a alegria, ou que se voltassem para o simples hedonismo festivo, eram imediatamente taxados de "entreguistas", "alienados" e até "colaboradores do regime" - como ocorreu com Wilson Simonal. Muitos artistas, não apenas da música, como também do cinema, literatura e teatro, ansiavam por mais autonomia artística e buscavam discutir outros temas, o que soava como alienação para os "patrulheiros", visto que essas visões mais otimistas e descompromissadas com a política não poderiam ser imediatamente identificados com uma "resistência".

Para Cunha (2009, p. 82), esses fatores que determinaram o esvaziamento também seriam os mesmos que ofereceram novas matérias-primas para diferentes maneiras de atualização cultural, novas demandas sociais e visões alternativas. Novos artistas e movimentos começaram a surgir questionando a autoridade intelectual da esquerda e denunciando seus privilégios enquanto representantes de minorias. Esses grupos não se sentiam representados por essas organizações tradicionais e passaram a produzir seus próprios repertórios de modas e linguagens locais, no ímpeto de criar diferentes maneiras de "estar no mundo" e de fazer política, para além das bases institucionais, buscando possíveis transformações no espaço do cotidiano. 
Mesmo sambistas negros criticavam o movimento pela sua falta de autenticidade cultural, já que o funk representava, para esse grupo, uma corrupção das tradições do samba. Essa rivalidade, incentivada e explorada pela mídia e gravadoras, basicamente foi encabeçada por Candeia, compositor criador da escola de samba Grêmio Recreativo de Artes Negras Quilombo, ${ }^{5}$ em 1975, que tinha uma atuação importante em relação à pesquisa e valorização das tradições musicais negras do Rio de Janeiro. O compositor chegou a declarar: "Não tememos a incompreensão de muitos, as calúnias de outros e nem as queixas de negros racistas”. (CANDEIA..., 1978, p. 135) Em 1977, gravou, com Dona Ivone Lara, o partido alto "Sou mais o samba": "Eu não sou africano, nem norte-americano/ ao som da viola e pandeiro/ sou mais o samba brasileiro”. Segundo Dom Filó, em entrevista a Essinger (2005, p. 41), isso foi uma estratégia de marketing da própria WEA, que era contratante tanto de Candeia quanto da SGP, como forma de criar polêmica e chamar a atenção para seus artistas. Mas frequentadores e fãs do samba e do Black Soul trocavam críticas efetivamente:

adeptos da música 'soul' afirmam ter desistido de ir às quadras de escolas de samba porque estas se haviam comercializado em demasia; sambistas consideram ser o 'Black Rio' um fenômeno eminentemente comercial e, por conseguinte de pouca qualidade". (CAVALCANTI, 1981, p. 16)

A leitora Rosa Nascimento, em carta enviada ao Jornal do Brasil em 22 de julho de 1977, denunciava o tratamento recebido pela Banda Black Rio na quadra da escola de samba Quilombo, em um evento voltado para festas populares. O grupo teria sido impedido de se apresentar pelos dirigentes da agremiação, que alegavam "preservar e divulgar as origens das manifestações artísticas populares".

5 O Grêmio Recreativo de Arte Negra e Escola de Samba Quilombo foi fundado pelos compositores Candeia, Nei Lopes, Wilson Moreira e Mestre Darcy do Jongo em 8 de dezembro de 1975, na Fazenda Botafogo, subúrbio do Rio de Janeiro. A escola de samba nunca foi filiada a nenhuma liga carnavalesca e não participa de desfiles competitivos. Suas atividades de resgate dos valores originais do samba incluem trabalhos culturais e sociais, especialmente voltados para a comunidade negra e pobre da região. 
Temendo a repressão, alguns DJs e equipes evitavam assumir posições políticas, garantindo que seus negócios tinham um mote apenas de entretenimento. A Lei de Segurança Nacional previa pena de detenção de um a três anos para quem incitasse publicamente ao ódio e à discriminação racial. (BRASIL, 1967, Art. 33, VI) Nirto, um dos donos da SGP, se defendia:

Você viu? Aquele festival de rock em Saquarema reuniu umas $30 \mathrm{mil}$ pessoas e não houve nenhuma restrição a nada. Então, poderíamos dizer também que está havendo movimento político no rock. E não está havendo. Não é nada disso. Simplesmente o rock, atualmente no Brasil, reúne mais pessoas brancas. Agora, o soul não; o soul atinge mais as pessoas negras. Este é o motivo de o soul reunir tantos negros, tantos blacks no Brasil. (FRIAS, 1976, p. 4)

Além disso, as equipes e os frequentadores começaram a ser considerados racista em relação aos brancos, pois existiam histórias de brancos barrados nos bailes soul. "O racismo começou com a Soul Grand Prix", afirmou Big Boy, na época (FRIAS, 1976, p. 5), ${ }^{6}$ corroborando a crença de que a discriminação e o preconceito racial poderiam ser acionados pelos negros mais radicais em relação aos brancos. Essa tese, como notaremos a seguir, também estava presente nas suspeitas da polícia secreta, que temia um clima de animosidade racial provocado pelos bailes black. Essas críticas eram questionadas por DJs como Mr. Funky Santos, que também não assumia a existência de um problema racial no Brasil, nem dava um tom político aos seus bailes:

Eu não acho que o soul Power seja um movimento racista. Porque eu acho que esse é um país onde a gente não deve implantar esse tipo de coisa, porque aqui, seja branco, seja negro, a gente deve estar lado a lado. Há aquelas barreirinhas, mas são muito pequenas. Então, se a gente for implantar um movimento desses, a gente está arriscando a se quebrar. Não é uma boa, eu não aconselho ninguém a fazer. Porque o soul é o caminho da comunicação entre os negros. Não é

6 Big Boy também afirma na mesma reportagem sua perda de mercado: "Atualmente, a Soul Grand Prix, que não tem a metade do material que eu tenho, ganha $\mathrm{Cr} \$ 10$ mil por baile. Eu ganho Cr\$ 5 mil”. (FRIAS, 1976, p. 5) 
um movimento negro. É um movimento de negros. (MR. FUNKY SANTOS, 1976, p. 4)

Ao enfatizar os bailes black como canais de comunicação entre negros, Mr. Funky sinaliza para o potencial político e de mediatização dessa cena musical, mas sem reconhecê-la como uma organização coletiva efetiva, com lideranças e pautas definidas. Havia sim uma finalidade política, quando os bailes de soul se tornam "um meio para atingir um fim - a superação do racismo”, como considera Vianna (1987, p. 57), mas que se consolidava na oferta de novos repertórios simbólicos e culturais que ressaltavam a capacidade de intervenção de seus atores sociais, propondo novas implicações para as políticas culturais brasileiras. Esse potencial foi reconhecido, apoiado e defendido pelas novas entidades do movimento negro da época, como o então recém-criado IPCN em 1976, que apoiava os blacks e cujos dirigentes mantinham estreita relação com a cena do soul. Carlos Alberto Medeiros, membro da diretoria do instituto, escreveu um editorial no Jornal da Música em agosto de 1977 defendendo a Black Rio:

É claro que dançar soul e usar roupas, penteados e cumprimentos próprios não resolve, por si, o problema básico de ninguém. Mas pode proporcionar a necessária emulação - a partir da recriação da identidade negra perdida com a Diáspora Africana e subsequente massacre escravistas e racistas - para que se unam e, juntos, superem suas dificuldades.

\section{Direita, ditadura e repressão}

As críticas ao soul partiam também de jornais considerados de direita, como O Globo. Em 26 de abril de 1977, na página dez da edição matutina, um editorial não assinado declarava o posicionamento do jornal:

É próprio da juventude escolher os seus próprios meios de expressão; e é comum que esses meios sejam esdrúxulos, excêntricos. Assim, não é por seus aspectos pitorescos, beirando às vezes o grotesco, que se deve condenar esse movimento batizado de 'soul', ou, na 
versão carioca, de ‘Black Rio’. O problema não está nas roupas, nos sapatos ou nos apelidos. Mas está no que esconde atrás de tudo isso: uma visão alienada da realidade, artificialmente estimulada por interesses nitidamente comerciais, e tendo por base um indisfarçado racismo [...]. Não se pode considerar autêntico, nem positivo qualquer movimento - musical, esportivo ou que outro pretexto tenha - que, em nome de uma manifestação artística, ou mesmo de simples entretenimento, procure dividir a sociedade brasileira com uma cunha [sic] racial. (RACISMO, 1977, p. 10)

Críticos conservadores aliados ao regime militar, como Gilberto Freyre, ${ }^{7}$ atacavam o movimento soul dizendo tratar-se de mera importação insidiosa dos discursos culturais e políticos afro-americanos irrelevantes para a "democracia racial” no Brasil. Em artigo intitulado “Atenção brasileiros”, publicado no Diário de Pernambuco em 16 de maio de 1977 e repercutido no Jornal do Brasil no dia seguinte, Freyre critica a articulação da afirmação racial com o marxismo, em uma militância que poderia provocar “ódios”, mas também conjuga duas formas de imperialismo que poderiam agir sobre o Brasil por meio desse movimento: o norte-americano capitalista e o soviético comunista. Ou seja, em uma intrincada perspectiva irrealista, Freyre considerava que duas forças historicamente antagônicas estariam se unindo e utilizando a juventude black da época como ferramenta de dominação do país.

Teriam os meus olhos me enganado? Ou realmente li que, dos Estados Unidos, estariam chegando ao Brasil - se é que já não se encontram - vindos da tradicionalmente muito amiga República dos Estados Unidos da América do Norte - por quem? - de convencer brasileiros, também de cor, que suas danças e seus cantos afro-brasileiros deveriam ser de melancolia e de revolta? [...] Se é verdade o que suponho ter lido' - escreve o autor de Casa Grande e Senzala - 'trata-se de mais uma tentativa da mesma origem no sentido de

7 É notório que Gilberto Freyre era um entusiasta do movimento militar de 1964, tendo sido convidado pelo marechal Castelo Branco a assumir o Ministério da Educação e colaborando com o regime nas perseguições a intelectuais. Para mais, ver: Gilberto Freyre: um vitoriano nos trópicos, de Maria Lúcia Garcia Pallares-Burke (2005). 
introduzir-se num Brasil crescentemente, fraternalmente, brasileiramente moreno - o que parece causar inveja a nações também bi ou tri-racionais nas suas bases - o mito de uma negritude, não a la Senghor, de justa valorização de valores negros ou africanos, mas que faria às vezes daquela luta de classes tida por instrumento de guerra civil. (SOCIÓLOGO..., 1977, p. 14)

Para Alberto (2009, p. 28), as críticas por parte da imprensa em geral acabaram por chamar a atenção também da ditadura, que passou a investigar bailes, DJs e produtores - apesar de que o DGIE, órgão de inteligência da polícia, havia começado suas investigações em abril de 1975, portanto, antes do artigo de Frias ter sido publicado. Essas reportagens serviram de suporte para embasar justificativas de investigação e a polícia secreta do regime começou a acompanhar as movimentações, com receio de estar sendo implantada no Brasil uma célula subversiva dos Panteras Negras ou de outros movimentos negros radicais norte-americanos. Os Panteras Negras (Black Panther Party for Self-Defense) foi um partido e organização fundado em 1966 por Bobby Seale e Huey Newton, inicialmente baseado em projetos sociais e educacionais voltados para a comunidade negra e para as crianças. Com o acirramento das tensões raciais, seus integrantes passaram a ser reprimidos pela polícia e logo estabeleceram táticas para se opor à violência do Estado, defendendo ações armadas em defesa da causa negra. ${ }^{8}$ Mas também apoiavam outras pautas ligadas a minorias como o movimento do Orgulho Gay, sendo os primeiros a endossá-lo. A imagem dos Panteras Negras despertava receio entre as autoridades brasileiras, pois a criação de um movimento com inspirações semelhantes no Brasil representava uma ameaça à propaganda e à comunicação oficial do governo militar, que tentava difundir uma imagem e um sentimento de união nacional, evitando qualquer referência a uma possível desarmonia racial, dentro ou fora do país. Isso valia também para imagens do cinema, e, segundo Hanchard (2001, p. 137), os censores foram instruídos a proibir quaisquer filmes que retratassem problemas raciais no Brasil ou

8 Autores como James Baldwin, de Numa terra estranha (1963), e Eldridge Cleaver, de Alma no exílio (1971), forneceram as bases filosóficas para a formação do grupo Panteras Negras. 
nos EUA, especialmente aqueles que abordavam diretamente o movimento Black Power. $^{9}$

Efetivamente, a ditadura já vinha exercendo repressão policial sobre outras manifestações de cunho artístico ou musical que tivessem relação com quaisquer protestos raciais. Em 1971, no VI FIC, realizado no Maracanãzinho, Tony Tornado e Elis Regina apresentaram a música "Black is beautiful”, composta pelos irmãos Marcos e Paulo Sérgio Valle. A composição, por si só, já havia sido censurada antes do lançamento. A letra original, segundo Palombini (2009), continha os versos "eu quero uma dama de cor / uma deusa do Congo ou daqui / que melhore o meu sangue europeu” foi substituída por "Eu quero um homem de cor / um deus negro do Congo ou daqui / que se integre no meu sangue europeu”, tanto para se adequar ao eu-lírico feminino na voz de Elis quanto para garantir que a herança europeia e negra fossem "igualadas" em termos de valor e importância, mantendo o ideal positivo da mestiçagem e da integração racial. Mesmo assim, a apresentação da canção ainda gerou polêmica e, durante a apresentação no festival, Tony Tornado levantou uma das mãos com o punho cerrado, gesto característico dos Panteras Negras, e acabou sendo preso ainda no ginásio. (PELEGRINI; ALVES, 2011)

Mas, inicialmente, a vigilância sobre os bailes tinha uma motivação de manutenção da "ordem e segurança pública", e era comum a revista a sacolas de disco em busca de drogas, quando os policiais chegavam ao absurdo de revistar o cabelo black dos frequentadores negros dos bailes (MARSIGLIA, 2015; PEREIRA, 2000), inclusive confiscando pentes-garfo, pois achavam que os dentes de metal poderiam ser usados como armas. (PIRES, 2015, p. 19) Se algum jovem negro fosse preso, via de regra, teria seu cabelo raspado. $\mathrm{O}$ policiamento, nesse caso, não era apenas sobre o caráter de mobilização política ou ação subversiva, mas também se referia à própria repressão institucional que faz parte da história da sociedade brasileira desde os tempos da

9 Hanchard (2001, p. 137) cita como exemplo de censura que representava a preocupação quase paranoica de se evitar qualquer discussão racial o caso de uma frase cortada de um artigo traduzido do jornal britânico Manchester Guardian sobre xadrez, que dizia: "Os brancos têm grandes vantagens materiais, enquanto os negros quase não têm abertura legal”. 
escravidão, em que o "elemento negro" e suas manifestações culturais eram vistos com suspeição pelas autoridades.

Quantas vezes já corri de pancadaria e invasões da polícia nos bailes do Greipe da Penha e também em Madureira, Marechal Hermes, Rocha Miranda. Umas duas vezes a polícia deu tiros dentro do clube Greipe para acabar com o baile. E se você fosse preso, tomava porrada e ainda te esculachavam. Um amigo meu, lá de Padre Miguel, que ia sempre aos bailes comigo e uma galera, foi preso e tosaram a cabeleira black power dele e feriram o couro cabeludo. (Ras Adauto)

Recentemente, em julho de 2015, a Comissão Estadual da Verdade do Rio de Janeiro (CEV-RJ) encontrou documentos que mostram como, a serviço da ditadura, investigadores passaram a vigiar artistas e produtores dos bailes com a suspeita de que um revolucionário afro-americano estaria no Brasil recrutando militantes para implementar no país um regime de segregação racial. ${ }^{10}$ A reportagem sobre a descoberta foi publicada no jornal $O$ Globo em 11 de julho de 2015, de autoria de Flávia Oliveira, que diz que o ponto de partida dos historiadores da CEV-RJ foi um informe de fevereiro de 1975, enviado pelo I Exército aos órgãos de informação, incluindo o Dops do antigo estado da Guanabara. No relatório intitulado Black Power (Informe 17/75-B), havia um alerta sobre a formação de um grupo de jovens negros " [...] de nível intelectual acima da média, com pretensões de criar no Brasil um clima de luta racial”. (OLIVEIRA, 2015) Eles estariam recebendo instruções e financiamento do exterior, e o local dos encontros era na quadra da escola de samba Portela.

O relatório também descrevia supostos objetivos do grupo: "Sequestrar filhos de industriais brancos; criar um bairro só de negros; criar ambiente de aversão aos brancos". Pelas informações contidas nos relatórios, as investigações eram conduzidas por policiais negros, que poderiam se infiltrar discretamente nos bailes sem causar maiores suspeitas. Mesmo sem conseguir

10 Ainda que a repressão sobre as escolas de samba não tenha começado com a ditadura, a censura e a repressão do regime militar também foram aplicadas às escolas de samba, segundo Hanchard (2001, p. 138): "era comum a polícia invadir as quadras de escolas de samba, nessa época, e fazer detenções indiscriminadas de até duzentos rapazes negros de cada vez, bem no meio da quadra". 
comprovar as denúncias, os relatórios serviram como justificativa para a perseguição aos organizadores dos bailes - equipes de som como Black Power e SGP e seus integrantes eram nominalmente citados. Os textos ainda traziam descrições detalhadas do público presente aos bailes, valor dos ingressos e até expressões usadas pelos frequentadores - ao $2^{\circ}$ Encontro dos Blacks, no Portelão, compareceram 6 mil "pessoas de cor", segundo o documento da Seção de Buscas Ostensivas.

Os responsáveis pelos bailes foram fichados e interrogados. Em 1976, Asfilófio de Oliveira Filho, o Dom Filó, da Soul Grand Prix, foi capturado perto do Renascença Clube, na saída da Noite do Shaft. Encapuzado, foi lançado num carro. Terminou numa sala úmida, com a visão ofuscada por uma luz forte. Passou a madrugada sob tortura psicológica, sem saber onde estava. A descrição do ambiente coincide com depoimentos de presos políticos que passaram pelo DOI-Codi, cuja sede ficava no Quartel do $1^{\circ}$ Batalhão da Polícia do Exército, na Rua Barão de Mesquita, na Tijuca. 'As vozes perguntavam onde estava o US\$ 1 milhão. Mas aquilo não existia', lembra Dom Filó, deixado horas depois no Lins de Vasconcelos. (OLIVEIRA, 2015)

O primo de Filó, Nirto, também foi detido e interrogado, na tentativa da polícia de confirmar a suspeita de que americanos estariam financiando o movimento. E começou-se a notar uma vigilância mais ostensiva dos bailes, com agentes infiltrados nas festas e até mesmo tentativas de forjamento de flagrantes de tráfico de drogas no escritório da equipe SGP, localizado na Central do Brasil, mas sem sucesso: "O esperto que tentou armar a tramoia acabou sendo desmascarado e, de forma cinematográfica, pendurado na janela do $23^{\circ}$ andar para confessar", conta Essinger (2005, p. 35). O cantor Gerson King Combo também foi detido, levado para a sede da Polícia Federal na Praça Mauá, Centro do Rio, e interrogado durante três horas, após desembarcar de um voo no aeroporto Santos Dummont. Ele era considerado pela polícia como "líder do movimento black". ${ }^{11}$ De fato, essa opinião era

11 Em entrevista a Moraes (2014, p. 27), o produtor e empresário de Gerson King Combo conta que sempre havia alguém da produção vigiando os bailes para dar o alerta caso a polícia apare- 
compartilhada com alguns veículos da imprensa, como O Globo. Em um editorial intitulado "Black Power in Brasil", o articulista Ibraim De Leve - provavelmente um pseudônimo para o colunista social Ibrahim Sued, já que a "de leve" foi uma expressão criada e frequentemente utilizada por ele - denuncia que um grupo não identificado estaria tentando deslanchar no país um movimento Black Power organizado e afirma: "O líder é o cantor Gerson King Gomho, e o vice-líder é Tony Tornado. O objetivo do movimento é instaurar o racismo nesse país, como existe nos Estados Unidos”. (DE LEVE, 1977) E segue denunciando que, nos bailes, os negros geram agitações e estimulam o confronto contra brancos, insuflando uma revolta racial no país. Esse temor tinha relação com a ideia de que o soul seria uma célula de esquerda, comunista e da "resistência".

Tony Tornado também era alvo das críticas da esquerda por seu canto "americanizado" e o acusavam de copiar a música estrangeira (ALONSO, 2011, p. 123), debochando de seu estilo que mimetizava James Brown. De certa forma, como considera Alonso (2011, p. 124), mesmo que Tony Tornado e, por conseguinte, Gerson King Combo e outros cantores brasileiros de soul compusessem e gravassem músicas que pregassem o protesto e a conscientização, nunca foram considerados artistas da "resistência", pois eram criticados de serem "copiadores" de uma musicalidade "importada”, portanto, alienada e menos legítima. O próprio Tim Maia, reconhecidamente influenciado pela música americana, disparou:

Faço música de preto. E os pretos precisam se convencer de que chegaram ao mundo dos brancos acidentalmente, em navios negreiros. Olha só isso que chamam de movimento Black Rio: os negros não passam de xerox dos americanos, que, por sua vez, imitam os brancos. Não sacam que o negócio é voltar para a África. (MOTTA, 2006, p. 127)

André Midani, presidente da WEA, que possuía vários artistas e equipes de soul em seu cast, veio em defesa dos blacks, se posicionando contra as

cesse, a fim de que pudessem esconder os discos de soul imediatamente, trocando as músicas e passando a tocar samba para disfarçar. 
críticas da "imprensa branca" que os acusavam de perda da negritude, representado pela rejeição ao samba. Em 1985, em entrevista ao Jornal do Brasil, Midani reafirma sua postura:

Eles congelam os negros como responsáveis por guardar a cultura brasileira intacta através dos anos. E no meu entender, isso é perigoso porque impede o negro de entrar na sala de jantar. Ele não tem o direito aos instrumentos eletrônicos, nem de usar e abusar das aventuras que a modernidade pode proporcionar a sua linguagem musical. (CARONE, 1985)

Midani ainda conta que, devido a comentários como esse, seu nome chegou ao Ministério da Justiça, apontado como receptor de fundos do movimento black americano, que estavam sendo utilizados para financiar uma guerrilha urbana a partir das favelas, mas o assunto não teve maiores consequências. O disco-jóquei Mounsieur Limá, que também estava lucrando bastante com o movimento e realizando concorridos bailes, defendia o fenômeno, não enfatizando sua autenticidade, mas realçando sua capacidade de "controle social”, garantindo a segurança na cidade, que deveria ser incentivado pelo governo: "Se não houvesse isso, eu garanto que haveria um aumento grande nos assaltos, nos finais de semana, o pessoal sem ter o que fazer, sem ter como se divertir”. (O SOUL..., 1976, p. 5) Apesar de não mencionar diretamente a juventude negra como alvo principal do comentário, o DJ ressaltou dois estereótipos clássicos relacionados ao negro, especialmente pobre, que é aquele que ou dança ou é criminoso. ${ }^{12}$

Mesmo com esses argumentos não tão enaltecedores, as investigações policiais continuaram e se estenderam a São Paulo e ao Rio Grande do Sul, cujos escritórios da Polícia Federal produziram relatórios com um mote comum: todas as investigações criminalizavam o movimento black e o acusavam de pregar entre jovens negros "o preconceito racial, a discórdia e o desentendimento nocivo à comunidade brasileira”. Havia também uma preocupação tácita em buscar conexões dos integrantes mais famosos com organizações

12 E, de fato, como defende Vianna (1988), era notória a ausência de álcool e drogas mais pesadas, bem como de graves atos de violência nos bailes de soul. 
comunistas, citando nominalmente Monsieur Limá, Tony Tornado, Big Boy, Ademir Lemos e membros das equipes, além de jornalistas como Tárik de Sousa, Lena Frias, Tarlis Batista, além do fotógrafo Almir Veiga. A repressão também recaiu sobre a questão administrativa das equipes, as movimentações financeiras, valores de ingresso, fluxo de caixa, segundo depoimento do professor da Universidade Federal Rural do Rio de Janeiro (UFRRJ), Pereira Amauri, ao programa Caminhos da Reportagem em 2014.

Em 1976, um documento de investigação policial que anexava reportagens como a de Lena Frias registrava a declaração de que o soul "explorava, de certa forma, o orgulho da negritude, o confronto entre brancos e pretos, e as rivalidades sociais e econômicas entre a Zona Norte e a Zona Sul do Rio de Janeiro". (ALBERTO, 2009, p. 28) Havia ainda nos relatórios a denúncia de que alguns bailes não aceitavam a entrada de brancos, como os da equipe Black Power - e que, por isso, havia sido banida do Grêmio Recreativo Rocha Miranda -, o que incorreria, tecnicamente, em um crime de discriminação racial, violando a lei Afonso Arinos de 1951, mas o que não gerou maiores repressões ou processos policiais contra os organizadores desses bailes. De qualquer forma, mesmo com a presença nos relatórios de denúncias de "radicalismos" nos bailes que proibiam ou dificultavam a entrada de brancos, alguns investigadores consideravam essa atitude um reflexo de práticas semelhantes em clubes de rock ou clubes sociais, como o late Clube do Rio de Janeiro, Hípico Brasileiro, o Clube Militar, frequentados por brancos na Zona Sul, que rotineiramente faziam a mesma coisa com indivíduos negros. (ALBERTO, 2009, p. 11)

Apesar das intensas investigações, não houve qualquer conexão mais forte com organizações comunistas ou grupos negros radicais americanos, e os investigadores passaram a focar nas implicações psicossociais do movimento, adotando a visão esquerdista de que os bailes de soul tinham apenas uma preocupação mercadológica, visto que a maioria dos organizadores e das equipes não fazia distinções em relação aos "tipos étnicos” dos frequentadores. Mas a pesquisa dos arquivos do DGIE por Pires (2015, p. 43) relata que não foi possível corroborar nenhuma das suspeitas da repressão, como a implicação de capital e membros estrangeiros no movimento do soul; a presença de atos contra brancos ou maiores animosidades raciais; o uso de drogas nos 
bailes; a crítica direta ao regime ou a presença de propaganda comunista, entre outros. E entre os meses de outubro e novembro de 1976, o DGIE encerrou as investigações.

O relatório da polícia que encerrou as investigações sobre o soul ecoou ainda mais a linguagem dos comentaristas da esquerda. Ele não apenas concluiu que qualquer confronto entre negros e brancos brasileiros era, em última análise, uma questão de música, moda e marketing, ao invés de uma consciência política, como também traduzia o pesar da esquerda de que o soul havia transformado uma real consciência revolucionária em uma espécie de alívio complacente, e que os seus frequentadores nunca teriam sido capazes de constituir uma ameaça real para o governo. (ALBERTO, 2009, p. 30)

A polícia finalmente percebeu que os bailes black eram apenas uma tentativa de reunir um grupo específico em torno de uma forma particular de música, estilo e lazer, mas ressaltando ainda uma distinção clara, presente em alguns pontos dos relatórios, que separava os frequentadores gerais, chamados de "pessoas de cor", daqueles que seriam mais engajados, considerados mentores desse movimento, os "negros" ou "blacks". De certa forma, um passo além da crítica produzida pela esquerda, pois sugeriam uma noção de diferença política fundamental entre a constituição de identidades locais difusas e a de identidades definidas a partir da importação de símbolos culturais internacionais (ALBERTO, 2009, p. 12), que no espaço dos bailes entravam em disputa na conformação de estilos particulares e diferentes. Mas a repressão assustou muitos donos de equipes, que ou modificaram paulatinamente o som de seus bailes, adotando sonoridades menos conectadas a uma sensibilidade black, passando a investir mais na disco music e no pop-rock, ou simplesmente abandonaram o negócio das festas.

\section{O fim dos bailes?}

Alguns autores, como Essinger (2005), Giacomini (2006), Mccann (2002), Thayer (2006) e Ribeiro (2008), consideram que a cena Black Rio começa a entrar em declínio no final dos anos 1970, por conta de fatores como a 
atenção negativa gerada pelas reportagens jornalísticas e a repressão da polícia da ditadura; críticas por parte da esquerda e de artistas ligados ao mundo do samba; e a introdução da disco music no mercado musical. A respeito da suposta definitiva substituição do soul pela disco, ${ }^{13}$ tanto nas gravadoras quanto no gosto dos públicos dos bailes, há algumas particularidades que dão a entender que, por um tempo, os dois gêneros conviveram, dividindo espaços e profissionais. Muitas equipes aderiram à disco, especialmente aquelas que não tinham uma preocupação mais clara com a questão racial e começaram a realizar bailes com vistas apenas na lucratividade. Isso não deixou de criar uma situação inédita, pois "a Zona Sul e a Zona Norte estavam dançando as mesmas músicas”. (VIANNA, 1987, p. 61) Com uma divulgação maciça pelas gravadoras, a disco music ainda foi tema de uma novela de enorme sucesso, Dancin' Days (1978-1979), que, ao lado do filme Os embalos de sábado à noite (1977), ajudou a difundir a moda da discoteca e tomou o espaço do soul na mídia e no gosto do público. A era disco teve uma duração curta, mas foi o suficiente para desarticular a cena black, e os bailes de soul voltaram a acontecer somente na periferia, em menor número. O segmento na indústria fonográfica também logo foi ocupado pela disco music e, depois, pelo rock e pelo pop, tanto nacional quanto internacional.

Os bailes black passaram a não ser mais tão concorridos, a exemplo do que ocorreu com a SGP. A equipe passou a ocupar tocar apenas em uma noite por semana, aos domingos, no Clube Condomínio, no bairro do Jardim Botânico, Zona Sul do Rio, eventualmente realizando bailes na Zona Norte, frequentemente dividindo espaço com outras equipes. A SGP também enfrentava problemas financeiros. Vianna (1987, p. 61) conta que a equipe trouxe para o Brasil o grupo norte-americano Archie Bell and The Drells, ligado ao Philly Soul, para realizar 17 apresentações junto com a equipe. O conjunto ganharia 10 mil dólares, "livres de despesas", por apresentação (FRIAS, 1976, p. 1), uma quantia vultosa para a época, mas a turnê foi um fracasso. ${ }^{14}$

13 Para saber mais sobre a ascensão da disco music no Brasil, ver: Essinger (2005) e Rodrigues (2003).

14 Segundo Frias (1976, p. 3), havia um projeto de trazer outros artistas da Philadelphia International Records para o Rio de Janeiro, empresariados por uma firma paulista, a Four Seasons, que acabou não se concretizando. 
Com o enorme prejuízo, a equipe foi obrigada a vender parte de seu equipamento de som para pagar as dívidas e passou também a realizar bailes de disco music, gerando desavenças entre a equipe e a saída de Dom Filó, que foi estudar nos EUA e retornou anos depois, criando com Carlos Alberto Medeiros uma produtora de vídeo. No entanto, até o começo da década de 1980, discos de soul ainda eram lançados, como as coletâneas assinadas por Mr. Funky Santos, mas já considerados uma espécie de flashback, rótulo logo associado aos bailes que continuaram tocando soul após os anos 1970 - em São Paulo, são chamados de festas "nostalgia" e também tocam clássicos do samba-rock.

Para alguns participantes do movimento, a superexposição da Black Rio na mídia e no mercado musical acabou por colaborar para sua decadência. A saturação acabou sendo inevitável, e o público se voltou para outras novidades. Alguns setores da imprensa e da esquerda mantinham constantes ataques ao caráter "mercantilista" dos bailes e das equipes, enquanto intelectuais e sambistas denunciavam os participantes da cena como "colonizados", "imitadores", que estariam colocando o samba e a cultura nacional em perigo. A TV também ajudou tanto na divulgação do movimento quanto na propagação de imagens e ideias associadas aos blacks que não colaboravam para uma visão positiva da Black Rio, especialmente quando sátiras passaram a ser feitas, a exemplo dos humoristas Os Trapalhões, cujos esquetes ajudaram a estigmatizar os blacks. Mas, mesmo que o contato e as negociações entre o movimento black e a mídia, a moda e o mercado pudessem repotencializar suas políticas de estilo na cultura da época, favorecendo novos diálogos e apropriações, o fato é que parece ter havido uma saturação do soul, especialmente em relação ao mercado musical.

Em declaração à revista Veja, Marco Mazola, da WEA, explicou que as leis de marketing da indústria do disco preconizam que as grandes vendas de discos "[...] dependem menos dos valores individuais do que das correntes e movimentos musicais”. (BLACK RIO, 1976, p. 156) Daí o investimento da gravadora no movimento Black Rio como forma de alavancar uma maior lucratividade. Mas, como qualquer "movimento", ele é provisório e se baseia em ciclos que se extinguem de acordo com o surgimento de novas tendências. Os inúmeros artistas brasileiros de soul foram deixando de gravar discos ou tiveram que se adaptar, se engajando em outros gêneros musicais depois 
que seus álbuns não mais alcançaram o sucesso de vendas esperado, em parte porque "a sonoridade dos arranjos nacionais (com exceção de Tim Maia) não agradaram aos dançarinos cariocas”, como justifica Vianna (1987, p. 60). Na verdade, os discos de soul brasileiro não agradaram aos críticos, pois alguns cantores venderam bastante, como Hyldon, Cassiano e ainda Cláudio Zoli. Em relação a Tim Maia, é notório que, nos anos 1980, continuou a vender discos, mas progressivamente abandonando uma sonoridade mais "funkeada” para se aproximar da música romântica popular mais comercial.

E ainda a MPB, mesmo vendendo menos que as músicas consideradas de "baixa qualidade" pela crítica musical, ocupou definitivamente o status de uma música socialmente valorizada, sinônimo de "bom gosto", oferecendo à indústria fonográfica a possibilidade de consolidar um catálogo de artistas e obras de realização comercial mais duradoura e inserção no mercado de forma mais estável e planejada, em álbuns mais bem acabados, complexos e sofisticados. Esses artistas de MPB continuavam a ser sustentados pelos álbuns de custo mais barato e artistas populares e também pelas coletâneas, sobretudo as trilhas sonoras de novelas, que garantiam alta lucratividade para investimentos a longo prazo nos artistas da "faixa de prestígio". Dada a lógica de segmentação de mercado, a "faixa de prestígio" e a "faixa comercial" não se anulavam, sendo complementares, já que investir apenas em sucessos populares instantâneos não compensaria os riscos de não possuir um elenco estável de compositores-intérpretes, bem como um conjunto de obras de catálogo, de vendas mais duráveis ao longo do tempo. (NAPOLITANO, 2002b, p. 5)

Se, em um primeiro momento, a produção comercial nacional de apelo popular foi tomada pela black music brasileira, no começo dos anos 1980, aos poucos, o lugar desse gênero passou a ser ocupado por outras vertentes, como a música romântica - Roberto Carlos, Fábio Jr. - e o "sambão-joia” Agepê, Benito di Paula -, entre outros. Nomes consagrados como Jorge Ben Jor e Tim Maia deram continuidade a suas carreiras de forma estável, consolidando-se definitivamente dentro da MPB. Apesar de manterem ainda influências do soul e do funk em seus discos, passaram a incorporar também influências da disco music e da dance music em uma tentativa de tornar mais comerciais suas produções musicais. Guardando suas especificidades, os 
dois músicos conseguiram estabilizar-se no mercado fonográfico justamente por desenvolverem estratégias midiáticas nas quais foram capazes de incorporar elementos da black music norte-americana à dicção da canção brasileira, influenciados ainda pela bossa nova e pelo samba. Bebeto, seguidor da batida de Jorge Ben Jor, acabou por superar seu antecessor e manteve um ritmo regular de produção de discos, vendendo milhares de cópias até final dos anos 1980, mantendo-se ativo em shows nos bailes das periferias. Aos poucos, foi condicionando seu estilo mais para um tipo de samba de contornos românticos, que influenciou fortemente os novos grupos de pagode na virada para a década de 1990, como Negritude Jr., Só Pra Contrariar, Raça Negra e Art Popular.

Vianna (1988, p. 11) aponta ainda para a permanência da realização em menor escala de bailes animados por "um funk mais antigo", baseado na sonoridade de pré-sintetizadores e com uma batida mais lenta, gênero posteriormente chamado de funk melody. Em paralelo, eram realizados também bailes nos quais se tocava uma variedade mais lenta de R\&B, que ficou conhecido como charme e acabou se desenvolvendo como uma outra cena musical suburbana, bastante ativa na atualidade. Criado por DJs como Corello e Fernandinho, de uma geração posterior, os bailes charme eram voltados para o moderno R\&B americano, cujos set lists eram compostos por hits mais melódicos e de andamento mais lento, de grande apelo comercial. Essa sonoridade era ideal para o desenvolvimento de elaboradas coreografias coletivas, executadas pelos frequentadores que chamavam a atenção pela elegância no vestir - o traje "esporte fino" era uma exigência para muitas dessas festas -, o que inspirou o termo "charme" para designar o novo movimento. Os bailes charme rivalizavam com o funk, que retornou à mídia no final dos anos 1980, a partir da atuação de equipes que haviam se tornado verdadeiras corporações, como a Hollywood e a Furacão 2000, ainda em atividade. Dirigida pelo empresário Rômulo Costa, a equipe se desmembrou em gravadora, programa de TV e de rádio, organizando bailes que chegavam a reunir 30 mil "funkeiros" - inclusive muitos de classe média - no Rio e em outros estados. Esse novo tipo de funk tocado nas festas era originário do subgênero Miami bass. E os militantes das várias tendências do movimento negro brasileiro carioca 
deixaram os bailes de lado, “[...] não mais considerando-os como um espaço propício para a conscientização”. (VIANNA, 1987, p. 62)

Já um discurso musical mais politizado consolidou-se nas periferias paulistas através do advento do rap. Equipes de baile locais, como a Chic Show e a Zimbawe - que depois se tornou um selo e lançou o grupo de rap Racionais MCs -, rivalizavam entre si e continuavam organizando grandes bailes e shows. Ao longo dos anos 1980, a Chic Show continuou atuante e foi responsável pela vinda ao Brasil de grandes nomes da black music americana, como Gloria Gaynor, Earth, Wind \& Fire e Cheryl Lynn. A equipe lançou várias compilações em LP e produziu programas de rádio. Em seus megaeventos, enquanto os DJs se revezavam nos toca-discos, os primeiros videoclipes de rap eram exibidos nos telões, divulgando um novo estilo de dança, o break, e, posteriormente, o rap e cultura hip hop.

Em Salvador, o movimento Black Soul teve repercussões específicas, contribuindo para o que Risério (1981, p. 23) chamou de "blackitude baiana”. Entre 1974 e 1980, surgiu uma série de blocos afro, organizações de Carnaval criadas por jovens negros influenciados tanto pelos discursos do Black Power norte-americano, quanto pelo pan-africanismo e o movimento de libertação anticolonialista das ex-colônias africanas - em especial, da África lusófona. O primeiro foi o Ilê Ayê, seguido pelo Malê Debalê, Olodum e Muzenza, agremiações voltadas para a promoção da cultura afro-brasileira, inspirados tanto pelo samba e pelo candomblé, mas também que tinham um cunho de luta contra a discriminação racial, encontrando eco em sonoridades como, particularmente, o reggae, que influenciou a constituição do gênero musical do samba-reggae.

Em um momento de questionamento das convenções e de movimentações sociais globais, a cena black e seus desmembramentos foram particularmente incentivados por um contexto social jovem, que valorizava o corpo, o desafio às convenções e apresentava diferentes formas de mobilização por vias alternativas, que também se davam no âmbito da intimidade e da subjetividade. Os bailes e a música ofereciam um refúgio simbólico para um grupo que se sentia excluído do discurso nacional baseado em uma identidade mestiça e harmônica. Os blacks, nos bailes, dançando e ouvindo soul, enfatizavam uma crítica não só ao autoritarismo do governo militar, mas também 
às tradicionais formas de luta e contestação, o que era visto por muitos como uma forma de escapismo despolitizado e por uma traição às tradições.

A Black Rio apontou para a oposição a uma cultura institucionalizada, ao racismo e ao autoritarismo, por meio de uma contestação de uma cultura nacional unificada (DUNN, 2009, p. 202), resistindo à repressão e às críticas por meios singulares, negociando com as instâncias mainstream da indústria cultural e apresentando uma rasura ao centro da identidade nacional a partir de suas margens. No próximo capítulo, discutirei como a materialização de novas políticas de estilo a partir da cena da Black Rio representava a assunção de papéis mais complexos e variados por uma juventude negra brasileira, que compartilhava códigos culturais globais como reação e estratégia para lidar como as novas demandas socioculturais do cotidiano. Reinterpretado e subvertendo o valor e as regras em torno da música e dos objetos de consumo cultural, o estilo dos blacks era resultado de uma polifonia de citações diversas, e tentarei reconstituir essas complexas genealogias, baseadas em releituras e apropriações que resultaram em novas políticas culturais negras. 